$\mathrm{M}$

етоды выявления антител класса M к антигенам T.pallidum для ранней диагностики сифилиса

С.В. Ротанов ${ }^{1,2}$, Р.Н. Чупров-Неточин ${ }^{2}$, Ф.А. Эрматова ${ }^{1}$

1 ГБОУ ВПО РНИМУ им. Н.И. Пирогова Минздрава России

117997, Москва, ул. Островитянова, д. 1

2 ФГБУ «Государственный научный центр дерматовенерологии и косметологии» Минздрава России 107076, Москва, ул. Короленко, д. 3, стр. 6

В обзоре рассмотрены вопросы, касающиеся современного применения лабораторных методов исследований для выявления в крови специфических иммуноглобулинов класса М против антигенов возбудителя сифилиса T. pallidum (иммуносерментный анализ, реакция иммунофрлюоресценции, линейный иммуноблоттинг). Определены показания и диагностические возможности указанных медицинских технологий для раннего выявления приобретенного и врожденного сифилиса, верификации случаев реинфекции и оценки активности течения инфекционного процесса у пациентов, ранее получавших специфическую терапию. Приведены рекомендации к использованию выявления специфических IgM, отраженные в современных российских и зарубежных руководствах и стандартах диагностики сисрилиса.

Ключевые слова: сифилис, методы исследования, иммуноглобулины класса М, реакция иммунофлюоресценции, иммуноферментный анализ, иммуноблоттинг.

Контактная информация: rotanov@cnikvi.ru. Вестник дерматологии и венерологии 2013; (1): 14-20.

\title{
Methods for the determination of M class anti- T.pallidum antibodies for early diagnostics of syphilis
}

S.V. Rotanov ${ }^{1,2}$, R.N. Chuprov-Netochin ${ }^{2}$, F.A. Ermatova ${ }^{1}$

${ }^{1}$ The Russian National Research Medical University named after N.I. Pirogov (RNRMU) Ostrovityanova street, 117997, Moscow, Russia

${ }^{2}$ State Research Center of Dermatovenerology and Cosmetology Ministry of Health Care of the Russian Federation

Korolenko street 3, bldg 6, 107076, Moscow, Russia

The review covers issues related to the present-day administration of laboratory blood test methods for the determination of specific Class M immunoglobulins against antigens of the syphilis pathogen, T. pallidum (immune-enzyme assay, immunofluorescence reaction, linear immunoblotting). Indications and diagnostic features of the aforesaid medical methods for early diagnostics of acquired or congenital syphilis were determined; cases of reinfection were verified and the intensity of the infection was assessed in the patients who had previously received specific treatment. The article provides recommendations for using specific IgM determination methods described in present-day Russian and foreign guides and standards of syphilis diagnostics.

Key words: syphilis, examination methods, Class M immunoglobulins, immunofluorescence reaction, immuneenzyme assay, immunoblotting.

Corresponding author: rotanov@cnikvi.ru. Vestnik Dermatologii i Venerologii 2013; 1: 14_20. 
При заражении сифилисом проникновение, персистенция и размножение возбудителя заболевания, T. pallidim, в организме хозяина приводят к активации механизмов как врожденного неспецифического, так и адаптивного, антиген-опосредованного иммунного ответа. В реализации механизмов иммунного ответа макроорганизма на инфекционный агент принимают участие множество разнообразных медиаторов клеточного обмена (провоспалительные и регуляторные интерлейкины, факторы роста и другие олигопептиды), повышенное содержание которых может определяться локально в очагах развития инфекции или в циркулирующей крови. Содержание указанных пептидов отражает выраженность защитной реакции макроорганизма, однако показатели их качественного и количественного содержания не являются характерными маркерами по отношению к антигенам возбудителя, вследствие чего они не могут служить для целей его идентификации или дифференциальной диагностики инорекционных заболеваний [1-3].

Эфрфекторные механизмы адаптивного (приобретенного) иммунного ответа макроорганизма на антигенную стимуляцию включают в себя гуморальное и клеточное звенья, соотношение этих элементов в протективном иммунитете при инфекциях во многом зависит от биологических свойств возбудителя заболевания [2-4].

Сифилис, вызываемый Treponema pallidum, относится к бактериальным инфекциям; реакции адаптивного иммунитета при этом заболевании осуществляются с участием гуморального звена, проявлением чего является выработка плазматическими клетками организма специфических антител, направленных против соответствующих антигенов возбудителя заболевания [2, 3, 6-22].

В соответствии с современными представлениями гуморальный ответ при сифилисе дебютирует появле- нием иммуноглобулинов класса М против наиболее иммуногенных и специфичных антигенов возбудителя. Антитела класса М имеют молекулярную массу порядка 970 кДа; по своей природе молекула IgM представляет собой пентамер, состоящий из 5 одинаковых субъединиц, каждая из которых сфрормирована двумя тяжелыми ( $\mu)$ и двумя легкими (к или $\lambda$ ) аминокислотными цепями (рисунок).

На одном конце каждой субъединицы иммуноглобулина М имеется по два антиген-распознающих Fab-фррагмента, способных за счет особой последовательности аминокислот своего вариабельного участка специфически распознавать и связывать определенный антиген, против которого он синтезирован. Другой конец субъединицы IgM имеет Fс-участок, благодаря которому 5 радиально расположенных субъединиц объединяются в единую структуру особым joint-белком.

Эволюционно антитела класса М относятся к наиболее древнему классу защитных антител. В сыворотке крови IgM составляют до 5-10\% от общего количества иммуноглобулинов; их биологическая функция состоит в максимальном связывании чужеродного антигена и подготовке его для последующего удаления из организма с привлечением фрагоцитирующих клеток. Благодаря своему строению IgМ могут связывать до 10 молекул антигена одновременно. Крупная величина молекулы и особенности структуры Fс-участков препятствуют проникновению $\lg$ через тканевые барьеры и сосудистые мембраны (в том числе через плаценту от матери в кровоток плода) [23-26].

Иммуноглобулины класса М определяются в крови уже на 10-14-й день после проникновения T. pallidum в организм человека, максимальное же их содержание у больных сифилисом приходится на 6-9-ю неделю заболевания [26-29]. После успешного лечения антибактериальными препаратами специфические

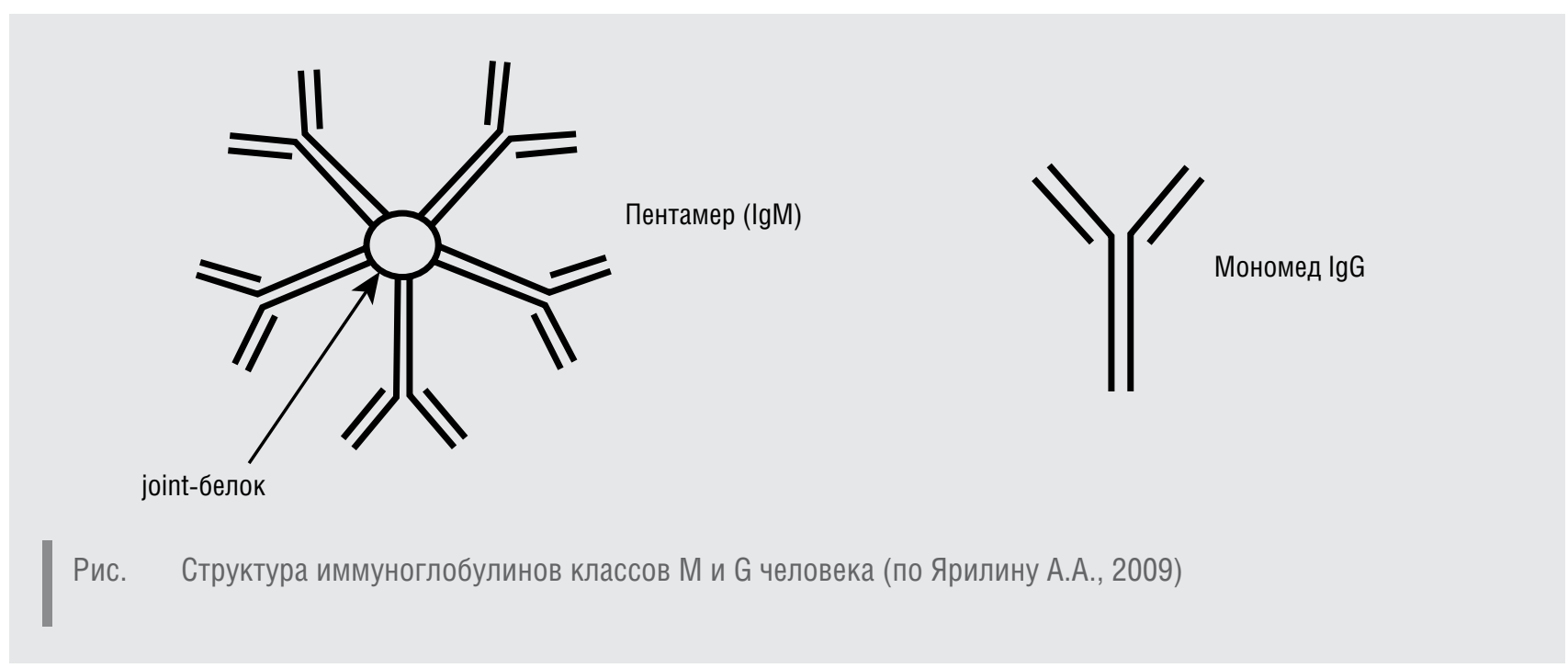


IgM у больных ранними формами сифилиса относительно быстро (через 3-12 месяцев) элиминируют из кровотока [24, 30-33].

Без лечения содержание иммуноглобулинов класса М в крови больных сифилисом постепенно начинает снижаться и происходит переключение синтеза IgM на выработку антител класса G [2, 3, 34].

Иммуноглобулины класса $\mathrm{G}$ в сравнении с IgM являются более мелкими белками с молекулярной массой 150 кДа. По своему строению они соответствуют одной из субъединиц $\lg$, в которой тяжелые цепи в структуре молекулы представлены $\gamma$-формами. Каждая молекула IgG способна связывать по две молекулы антигена. За счет меньшей величины и свободного Fc-фррагмента иммуноглобулины класса $\mathrm{G}$ являются более мобильными, они хорошо проникают через сосудистые мембраны, некоторые тканевые барьеры и плаценту [23, 25]. IgG составляют до $75 \%$ общего пула иммуноглобулинов крови, их биологическая функция заключается в специфическом связывании антигена в труднодоступных для других крупных молекул иммуноглобулинов участках макроорганизма

Специфические иммуноглобулины класса G в кровотоке больных сифилисом появляются более поздно, в конце 3-й или на 4-й неделе после заражения. Содержание специфических IgG постепенно увеличивается, достигает максимальной выраженности через 1-1,5 года, после чего несколько снижается, подвергаясь волнообразным колебаниям в зависимости от активности инфекционного процесса [24, 26, 28, 34]. Количество специфических $\lg \mathrm{G}$ в циркулирующей крови после адекватно проведенного лечения снижается медленно, они продолжают определяться в течение десятков лет или пожизненно [30-34].

Кроме перечисленных видов антител в гуморальном иммунитете при сифилисе принимают участие иммуноглобулины класса A, которые могут быть представлены в виде мономеров и димеров (соединенных между собою двух субъединиц, напоминающих $\operatorname{lgG}$ ), в которых тяжелые цепи представлены $\alpha$-фрормами. В сыворотке крови содержание IgA может достигать $15-20 \%$ от общего пула иммуноглобулинов в основном в виде двухвалентных мономеров. Антитела класса А секретируются на поверхности слизистых оболочек пищеварительного тракта, дыхательных, половых и мочевыделительных путей в виде четырехвалентных димеров; они усиливают защитные барьерные функции слизистых оболочек. IgA не способны проникать в кровоток ребенка через систему плацентарного кровообращения и могут быть использованы для диагностики врожденного сифилиса [3, 24, 35, 36].

Для выявления сифилиса при обследовании населения в настоящее время широко используются иммунологические (серологические) исследования, основанные на выявлении в жидких средах организма (крови или цереброспинальной жидкости) специфиче- ских иммуноглобулинов, направленных против характерных для возбудителя антигенных детерминант. Используемые лабораторные методы позволяют выявлять суммарный пул специфических антител классов M, G и A или дифференцированно антитела класса G или $\mathrm{M}[9,10,13,14-22,25,37-39]$.

Для выявления пула специфических антител (суммарно) при сифилисе применяют такие лабораторные методы, как иммуноферментный анализ (ИФА), реакция пассивной гемагглютинации (РПГА), реакция непрямой иммунофлюоресценции (РИФ), иммуноблоттинг (ИБ), иммунохроматографические (ИХГИ) и иммунохемилюминесцентные (ИХЛИ) исследования $[9,10,18,19 ; 21,22,39,41,42]$. Изучению клинической информативности указанных методов исследования в XX веке было посвящено значительное количество научных работ.

Диффференцированно определять в биологических жидкостях больного сифилисом содержание специфрических антител класса G или М позволяют ИФА и иммуноблоттинг за счет использования в качестве вторичных антител (конъюгатов) моноклональных антител к несвязанному Fc-фррагменту молекулы IgG или к н-форме тяжелой аминокислотной цепи, характерной для IgM [28, 34, 43].

Диагностическая информативность выявления специфических IgG при сифилисе изучена в большей степени, и это обусловлено более ранней разработкой технологии получения моноклональных антител для выявления иммуноглобулинов класса G. Клинические исследования по изучению диагностической информативности выявления IgM при сифилисе в научной литературе представлены в существенно меньшей степени, что связано с проблемами, связанными с разработкой высокочувствительных лабораторных технологий определения указанного класса антител.

При создании диагностических наборов реагентов для выявления IgM на основе ИФА традиционно используют два подхода. Первый из них (классическая сэндвич-технология) заключается в связывании антигеном $T$. pallidum, фриксированном на твердой фразе, специфических иммуноглобулинов всех классов, содержащихся в исследуемом образце, с последующим выявлением среди них IgM с помощью конъюгата на основе моноклональных сывороток против $\mu$-фрормы тяжелой цепи [28, 34, 44]. Недостаточная чувствительность описанной методики определения специфических IgM обусловлена конкуренцией между антителами разных классов за специфические сайты связывания антигеном на твердой фазе при существенно более низком содержании антител класса М в сыворотке крови по сравнению с антителами классов $\mathrm{G}$ и $\mathrm{A}[38,40]$.

Другой подход состоит в связывании на первом этапе моноклональными сыворотками к $\mu$-форме тяжелой цепи, сорбированными на твердой фазе, всех 
иммуноглобулинов класса М из исследуемого образца (технология «ловушки для антител», antibody capture ELISA) с последующим выявлением среди них специфических антител к антигенам возбудителя сифилиса. Это более чувствительный метод исследования, но и при нем имеются трудности обеспечения высокой чувствительности исследования, обусловленные количественными соотношениями антител различной специфичности в общем пуле иммуноглобулинов класса М $[8,28,38]$.

В ряде исследований была в сравнительном аспекте изучена клиническая информативность определения IgM методом ИФА. Так, Ляховым В.Ф. и др. (1990) при обследовании 73 больных разными клиническими формами сифилиса с применением разработанных авторами оригинальных наборов реагентов

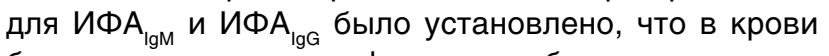
больных первичным сифилисом наблюдается максимальное содержание IgM при минимальном уровне IgG. При массовой диссеминации бледных трепонем, наблюдаемой при вторичном сифилисе, происходит снижение содержания IgM в крови и значительное нарастание специфических IgG антител. Авторы отметили, что на начальных этапах развития инфекционного иммунитета при сифилисе происходит образование антител к видоспецифическим белковым антигенам T. pallidum, а затем вырабатываются антитела к группо- и типоспецифическим детерминантам, то есть сначала появляются антитрепонемные, а затем антилипоидные антитела [28].

В исследовании Чепурченко Н.В. и др. (2001) была показана разная чувствительность ИФА стике отдельных клинических фрорм у 190 больных сифрилисом: при первичном - 78,8\%, вторичном - 51\%, скрытых формах - 24,3\%; при этим клиническая чувствительность ИФА ${ }_{\mathrm{IgG}}$ составила 78,8, 100 и 100\% соответственно. Специфичность результатов исследования в ИФА ${ }_{\text {lgм }}$ составила 100\%, а ИФА $\mathrm{IgG}_{\mathrm{lg}}-99,4 \%$ [45].

Несколько более высокие показатели клинической чувствительности были получены при исследовании 304 образцов сыворотки, полученных от больных сифилисом: при первичном - 89,1\%, вторичном 82,4\%, всех скрытых формах - 15,4-34,4\% [42].

С представленными данными согласуются результаты исследования Schmidt B.L. et al. (2000), проведенного с 52 образцами сыворотки крови больных первичным сифилисом, которые показали отсутствие антител к антигенам $T$. pallidum в реакции микрогемагглютинации (МНА-ТР), являвшейся основным отборочным тестом в ряде стран Европы.

Исследование этих образцов продемонстрировало положительные результаты в ИФА ${ }_{\mathrm{lgG}}$ с двумя наборами реагентов - в 22,6-63,4\%, в ИФА $\mathrm{lgG}+\mathrm{lgM}$ с шестью различными наборами реагентов - в 48,5-76,9\%, в ИФА ${ }_{\text {Igм }}$ с одним набором реагентов - в 86,5\%. Авторами указано на ограничение использования ИФА в качестве отборочного теста для скрининга сифилиса из-за недостаточно высокой специфичности его результатов (91\%) [38].

Отличающиеся результаты диагностической информативности ИФА нии Киселевой Г.А. и соавт. (2000) при сравнительных испытаниях 3 наборов реагентов для выявления сифрилиса в ИФА ${ }_{\operatorname{lgm}}$ разных производителей. Кроме того, авторами показана высокая клиническая чувствительность ИФА ${ }_{\text {Igм }}$ при ранних клинических формах заболевания: при первичном - 80-100\%, при вторичном 88,9-100\%, при скрытом раннем сифилисе - 48,3$92,9 \%$, при всех формах активного сифилиса и у больных с серорезистентностью - 52,9-75,8\%. При этом были установлены высокие показатели клинической специфичности исследований - 82-100\% [47].

При обсуждении современных методов исследования, применяемых для диагностики сифилиса, авторы характеризуют чувствительность ИФА ном сифилисе на уровне 78-93\%, вторичном - 5185\%, скрытых фрормах - 24,3-64\% [48-50].

После успешно проведенного лечения больных свежими формами сифилиса отрицательные результаты ИФА ${ }_{\text {ggм }}$ определяются через 6 и 12 месяцев в 71 и 92\% случаев соответственно [51], при этом некоторые авторы отмечают персистенцию в крови антител указанного класса до 18 месяцев после окончания терапии [52].

Рядом исследователей было показано выявление в крови иммуноглобулинов класса М как маркера присутствия в макроорганизме возбудителя у больных с реинфекцией и неудачами проведения антибактериальной терапии [20, 28, 53, 54].

Недостаточно высокие показатели диагностической информативности (чувствительности и специфричности) отечественных наборов реагентов для ИФА ${ }_{\text {Igм }}$ вызывают недовольство клинических специалистов, использующих результаты указанных исследований для диагностики сифилиса [48, 55-57].

Одним из высокочувствительных методов исследования специфических антител класса М является реакция иммунофлюоресценции (РИФ) [38, 40, 58]. Для осуществления РИФ $\Phi_{\operatorname{lgm}}$ из образца сыворотки крови либо выделяют 19S фрракцию (IgM антитела), используя ионообменную хроматографию или ультрацентрифугирование в градиенте плотности, либо удаляют фракцию $\lg \mathrm{G}$ антител [38, 40, 59].

Schmidt B.L. et al. (1994) при сравнительном изучении разных методов выявления специфических IgM при сифилисе было убедительно показано преимущество применения 19S IgM FTA-abs: положительные результаты выявления IgM при использовании этого метода были получены в $100 \%$ случаев у пациентов с первичным и вторичным и в 96,0\% - с ранним скрытым сифрилисом, в то время как в ИФА Elisa) наблюдали 100, 96,3 и 89,8\% положительных результатов соответственно [40]. В более поздней рабо- 
те авторами были подтверждены более высокие показатели клинической чувствительности метода 19S IgM FTA-abs при диагностике сифилиса $(90,4 \%)$ по сравнению с FTA-abs (44\%) [38].

В работе Гусевой С.Н. и Данилова С.И. (2004) методом IgM-РИФ абс исследованы образцы крови 55 беременных, у которых при первичном обследовании на сифилис были получены положительные результаты в одном из иммунологических тестов (КСР, РИФ фицированный способ определения специфических IgM для верификации результатов исследования: на подготовительном этапе из образцов сыворотки крови удаляется сывороточный IgG (до 95\%) путем его осаждения на стафилококковом реагенте, содержащем сухой белок А. Исследование в $\lg$ М-РИФ позволило выявить положительные результаты в 14 (25\%) случаях, что явилось основанием для постановки диагноза скрытого раннего сифилиса. Авторы рекомендовали разработанный метод исследования для внедрения $[58,60]$, однако до настоящего времени широкого применения в практическом здравоохранении он не получил.

ЗАО «ЭКОлаб» была предложена методика IgMРИФ абс $с$ предварительной обработкой образцов сыворотки крови RF-сорбентом (rheumatoid factor), предотвращающим неспецифическое влияние на результаты исследования ревматоидного фактора сыворотки крови и предупреждающего вытеснение из реакции специфических антител класса М антителами класca G. При исследовании образцов сыворотки крови 144 больных сифилисом и 100 здоровых лиц в ИФА и IgM-РИФ было получено полное совпадение результатов [61]. Клиническая доступность предложенного метода исследования и разработанный для этого диагностический набор реагентов позволяют проводить расширенные клинические исследования для оценки его диагностической информативности.

Исследование образцов сыворотки крови больных с клиническими проявлениями врожденного сифилиса показало высокую клиническую чувствительность выявления антител класса М в относительно новом методе исследования - IgM иммуноблоттинге - 92\% [62].

Изучение образцов сыворотки крови в IgM иммуноблоттинге было проведено Meyer M.P. et al. (1994) у новорожденных с врожденным сифилисом с клиническими проявлениями и без проявлений, а также у детей без сифилиса, рожденных от перенесших сифилис серопозитивных и не болевших сифилисом матерей. Положительные результаты определения IgM к антигену TpN47 наблюдали в 92, 83, 10 и 0\% случаев; кроме этого, у новорожденных была установлена различная частота выявления антител в отношении антигенов T. pallidum с разной молекулярной массой (от 15 до 110 кДа) [63].

В настоящее время исследователями предложены новые лабораторные методы и соответствующее аппаратное обеспечение для определения специфических IgМ при диагностике сифилиса, в том числе с использованием технологии проточной флюорометрии (хМАР) и иммуноферментного исследования на основе белковых микробиочипов [50, 64, 65].

Используя наборы реагентов BioPlex на основе калиброванных микросфер, Gomes E. et al. (2010) показали более высокую чувствительность иммунологического выявления специфических антител класса $\operatorname{lgM~c~регистрацией~результатов~лазерным~проточным~}$ флюорометрическим датчиком в сравнении с методикой их исследования в ИФА ${ }_{\mathrm{IgM}}$ [66].

Таким образом, для ранней диагностики инфекционных заболеваний, в том числе и сифилиса, а также дифференциальной диагностики случаев врожденного сифилиса или реинфекции показано лабораторное исследование образцов сыворотки крови пациентов с выявлением в первую очередь специфических иммуноглобулинов класса М. Для определения специфических IgM разработаны различные методики исследования, но их чувствительность зависит от стадии инфекционного процесса и качества используемых диагностических наборов реагентов.

Применение результатов определения специфических антител класса М к антигенам T. pallidum при диагностике сифилиса регламентировано многочисленными алгоритмами обследования пациентов [8-10, $25,29,34,37,40]$, а также действующими методическими рекомендациями и стандартами [11-14, 16, 17, 20-22, 39, 41, 50]. Появление новых методов исследования трепонемоспецифических IgМ требует клинической оценки их диагностической информативности на репрезентативной выборке пациентов. I
1. Roitt I., Brostoff J., Male D., eds. Immunology. 6th ed. Edinburgh; New York: Mosby.2001. [Ройт А., Бростофф Дж., Мейл Д. Иммунология: перевод с англ. М.: Мир, 2001.]

\section{Литература}

2. Kaskin K.P. Immunological researches in clinic of infectious diseases. News of applied immunology and allergology. 2004; (8): 1—10. [Кашкин К.П. Иммунологические исследования в клинике инфекционных заболеваний. Новости прикладной иммунологии и аллергологии 2004; 8: 1-10.]
3. Yarilin A.A. Immunology. Moscow: GJeOTAR-Media 2010. [Ярилин А.А. Иммунология. М.: ГЭОТАРМедиа, 2010.] 
4. Garib F.Y.T- and B- systems of lymphocytes of the human: Text of lec-tures. Tashkent: TashMl Publ., 1987: 12. [Гариб Ф.Ю. Т- и В-системы лимфоцитов человека: Текст лекций. Ташкент: Изд-во ТашМИ, 1987; 12 .]

5. Haitov P.M. Immunology. Moscow : GJeOTAR-Media 2009. [Хаитов Р.М. Иммунология. М.: ГЭОТАРМедиа, 2009.]

6. Masetkin I.P., Reznikova L.S., Luchnikova T.A., Elkin V.D. Serological diagnosis of syphilis. 1977. [Масеткин И.П., Резникова Л.С., Лучникова Т.А., Елькин В.Д. Серодиагностика сифилиса. Учебнометодическое пособие. Пермь, 1977.]

7. Ovchinnikov N.M., Bednova V.N., Delektorsky V.V. Laboratory diag-nostics of diseases, sexually transmitted. Moscow: Medicina Publ. 1987. [Овчинников H.M., Беднова В.Н., Делекторский В.В. Лабораторная диагностика заболеваний, передающихся половым путем. М.: Медицина, 1987.]

8. Petrishina S.V. Laboratory diagnostics of a syphilis. Russian Journal of Skin and Sexually Transmitted Diseases 2004; (2): 46—-49. [Петришина С.В. Лабораторная диагностика сифилиса. Российский журнал кожных и венерических болезней 2004; 2: 46-49.]

9. Frigo N.V. Standards and algorithms for the diagnosis of syphilis in Russia and abroad. Proc. V congress of dermatovenerology of republic of Bela-rus.abstracts. Topical issues of Dermatology, Venereology and dermatocosmetology. Minsk: «DoktorDizajn», 2006: 143-149. ГФриго Н.В. Стандарты и алгоритмы диагностики сифиллиса в России и за рубежом. Актуальные вопросы дерматологии, венерологии и дерматокосметологии: Материалы V съезда дерматовенерологии Республики Беларусь. Минск: «ДокторДизайн», 2006: 143-149.]

10. Frigo N.V. Laboratory diagnostics of a syphilis Moscow: GJeOTAR-Media 2009 T. I: 617-642. [Фриго Н.В. Лабораторная диагностика сифилиса. В кн.: Скрипкин Ю.К., Бутов Ю.С. (ред.). Клиническая дерматовенерология: в 2-х т. М.: ГЭОТАР-Медиа, 2009; Т. І: 617-642.]

11. Sokolovsky E.V., Frigo N.V., Rotanov S.V. et al. The guide to laboratory diagnostics of syphilis in countries of Eastern Europe.Vestnik dermatologii i venerologii 2008; (5): 87-96. [Соколовский Е.В., Фриго Н.В, Ротанов С.В. и соавт. Руководство по лабораторной диагностике сифилиса в странах Восточной Европы. Вестник дерматологии и венерологии 2008; 5 : 87-96.]

12. Sokolovsky E.V., Savicheva A.V. The laboratory diagnosis of syphilis. SPb : N-L Publ 2009. [Соколовский Е.В., Савичева А.М. и соавт. Лабораторная диагностика сифилиса: метод. рекомендации. СПб.: Изд-во Н-Л., 2009.]

13. Kubanova A.A. Dermatovenerology. Clinical Guidelines. Moscow: ZAO FID Delovoi express 2010: 347386. [Кубанова А.А. (ред.) Дерматовенерология. Клинические рекомендации. 4-е изд., перераб. и дополн. М.: ДЕКС-Пресс, 2010: 347-386.]

14. Kubanova A.A., Frigo N.V., Rotanov S.V., et al. Modern approaches and prospects of development of laboratory diagnostics for sexually transmitted infections. Vestnik dermatologii i venerologii 2011; (5): 54—63. [Кубанова А.А., Фриго Н.В., Ротанов С.В. и соавт. Современные направления и перспективы развития лабораторной диагностики инфекций, передаваемых половым путем. Вестник дерматологии и венерологии 2011; 5: 54-63.]
15. Fakhretdinova H.S., Imelbaeva E.A., Gilmanov A.Zh. About a signifi-cance of the modern serological research technigues of a syphilis at children and teenagers. XI ST Congress of dermatology and venereology of Russia. Abstracts 2010: 14. [Фахретдинова X.С., Имельбаева Э.А., Гильманов А.Ж. 0 значимости современных серологических методов исследования сифилиса у детей и подростков. Тезисы научных работ XI Всероссийского съезда дерматовенерологов и косметологов. Екатеринбург, 2010: 14.]

16. Young H. Syphilis: new diagnostic directions. Int J of STD AIDS 1992; 3: 391—413.

17. Young H. Guidelines for serologic testing for syphilis. Sex Transm Inf 2000; 76: 403—-405.

18. Larsen S.A., Steiner B.M., Rudolph A.H. Laboratory diagnosis and in-terpretation of test for syphilis. Clin Microbiol Rev 1995; 8 (1): 1 -21.

19. Larsen S.A. (Ed.), Pope V., Johnson R.E., Kennedy E.J. Manual of tests for syphilis. 9-th Ed. Washington: DC, 1998.

20. Egglestone S.I., Turner A.J.L. Serological diagnosis of syphilis. Com-mun Dis Public Health 2000; 3: 158162.

21. Goh B.T., van Voorst Vader P.C. European guidelines for the manage-ment of syphilis. Int J STD AIDS. 2001; 12 (Suppl. 3): 63—68. URL: http//:tutJ.Std/ Aids_oct2004.v1253.

22. Sexually Transmitted Infections: UK National Screening and Testing Guidelines. Screening Guideline Steering Group, BASHH Clinical Effective-ness Group. London, 2006. URL: http://www.sti.org/guidelines/2006.

23. Hemmings W.A. Motherfoetal transmission of immunoglobulins. Cam-bridge, 1975.

24. Baker-Zander S.A., Roddy R.E., Handsfield H.H., Lukehart S.A. IgG and IgM antibody reactivity to antigens of Treponema pallidum after treatment of syphilis. Sex Transm Dis 1986; 13: 214-220.

25. Akovban V.A.,Nesterenko V.G. Syphilis. Diagnostics. Moscow: medi Media Sphera Publ.ru2007: 306 —323. [Аковбян В.А., Нестеренко В.Г. Глава 7. Сифилис. Диагностика. В кн.: Аковбян В.А., Нестеренко В.Г. Инсрекции, передаваемые половым путем. М.: Медиа Сфера, 2007: 306-323.]

26. Krasnoselskich T.V., Sokolovsky E.V.The modern syphilis: epidemiol-ogical tendencies and achievements in the field of Treponema pallidum studying. Modern problems of dermatovenerology,immunology and medical cosmetology. 2010; (1): 84 — 87. [Kраcносельских Т.В., Соколовский Е.В. Современный сифилис: эпидемиологические тенденции и достижения в области изучения Treponema pallidum. Проблемы современной дерматологии, венерологии и косметологии 2010; 1: 84—87.]

27. Kern A. Fundamentals and prospects of syphilis serology. Dermatol Monatsschr 1979; 165 (11): 769—782.

28. Lyachov V.F.,Borisenko K.K., Potekaev N.S., et al. Dynamics of a treponemospecific immunoglobulinemiya at early forms of a syphilis.Vestnik der-matologii venerologii. 1990; (8): 38—-42. [Ляхов В.Ф., Борисенко К.К., Потекаев Н.С. и соавт. Динамика трепонемоспецифической иммуноглобулинемии при ранних формах сифилиса. Вестник дерматологии и венерологии 1990; 8: 38—42.]

29. Luger A. Serological diagnosis of syphilis; current methods. In Young H., McMillan A. (Eds.). Immunological diagnosis of sexually transmitted diseases. N-Y: Marcel Dekker, 1998: 249—274.

30. O'Naill P., Nicol C.S. IgM class antitreponemal antibody in treated and untreated syphilis . Brit J Vener Dis 1972; 48: 460—463.
31. Wilkinson A.E., Rodiv P. IgM-FTA test in treated in adults: its relation to clinical findings . Brit J Venereal Dis 1976; 52: 219-223.

32. Merlin S., Andre J., Alacoque B. et al. Importance of specific lgM anti-bodies in 116 patients with various stages of syphilis. Genitourin Med 1985; 61(2): 82—87.

33. Isinaga M., Sasaki E. Clinical survey of syphilis at the Dermatological Clinic of Nippon Medical School Hospital from 1984 to 1988, with special ref-erence to the recent clinical manifestation and evaluation of $\lg M$ antibodies to Treponema pallidum. J Dermatol 1990; 17(10): 618-629.

34. Tkachev V.K.,Vyatkina T.G.Syphilis IFA-diagnostics: information and methodical book 2005. [Ткачев B.K. Вяткина Т.Г. ИФА-диагностика сифиллиса: инсформационно-методическое пособие 3-е изд. 2005. URL: http://www.vector-best.ru/brosh/9607.htm.]

35. Schmitz J.L., Gertis K.S., Mauney C. et al. Laboratory diagnosis of con-genital syphilis by immunoglobulin $M$ (IgM) and IgA immunoblotting . Clin Diagn Lab Immunol 1994; 1: 32-37.

36. Pedersen N.S., Sheller J.P., Ratnam A.V., Hira S.K. Enzymelynked Immunosorbent Assays for Detection of Immunoglobulin M to Nontreponemal and Treponemal Antigens for the Diagnosis of Congenital Syphilis. J Clin Microbiol 1989; 27(8): 1835—1840.

37. Lomonosov K.S. Actual interview. New in the diagnosis and treatment of syphilis.Russian Journal of Skin and Sexually Transmitted Diseases 2002; 5: 56—60. [Ломоносов К.С. Актуальное интервью. Новое в диагностике и терапии сифилиса. Российский журнал кожных и венерических болезней 2002; 5: 56-60.]

38. Schmidt B.L., Edjlalipour M., Luger A. Comparative evaluation of nine different enzymelinked immunosorbent assays for determination of antibodies against Treponema pallidum in patients with primary syphilis. J Clin Microbiol 2000; 38(3): 1279_-1282.

39. Kubanova A.A. (Editor) Guidelines for the management of sexually transmit-ted infections and urogenital infections Moscow : ZAO FID Delovoi express 2012. [Кубанова А.А. (ред.). Клинические рекомендации по ведению больных инфекциями, передаваемыми половым путем, и урогенитальными инсекциями. М.: Изд. доМ «ДЕЛОВОЙ ЭКСПРЕСС», 2012.]

40. Schmidt B.L., Luger A., Duschet P. et al. Spezifische IgM-Teste in der Syphilis-Diagnose. Hautarzt 1994; 45(10): 685-689.

41. Order No. 87 "About improving serological syphilis diagnostics" issued by the Ministry of Health Care of the Russian Federation on March 26, 2001 and Appendix №. 1 "Screening and diagnostic syphilis tests". [Приказ Минздрава РФ № 87 от 26.03.2001 г. «0 совершенствовании серологической диагностики сифилиса» и Приложение № 1 «Постановка отборочных и диагностических тестов на сифилис».]

42. Kitaeva N.V.,Frigo N.V., Melechina L.E. Actual problems of syphilogy. The modern technologies of diagnostics of a syphilitic infection Vestnik dermatologii i venerologii. 2008; (5): 51—59. [Китаева Н.В., Фриго Н.В., Мелехина Л.Е. Актуальные проблемы сифилидологии. Современные технологии диагностики сифилитической инфекции. Вестник дерматологии и венерологии 2008: 5: 51—59.]

43. Sidorova E.V., Lyachov V.F. Value of definition of IgM-antibodies in a syphilis serodiagnosis. STD. 1995; (4): 11—14. ГСидорова Е.В., Ляхов В.Ф. Значение определения противотрепонемных IgM-антител в серодиагностике сисилиса. ЗППП 1995; 4: 11-14.] 
44. Zrein M., Maure I., Boursier F., Soufflet L. Recombinant antigen-based enzyme immunoassay for screening of Treponema pallidum antibodies in blood bank routine. Clin Microbiol 1995; 33(3): 525—527.

45. Chepurchenko N.V., Gladysheva M.V., Burkov A., at al. Preliminary results approbation of immunoenzymatic test system for definition of treponemspecific IgM. VIII ST Congress of dermatology and venereology of Russia. Abstracts. Moscow 2001. [Чепурченко H.B., Гладышева М.В., Бурков А.Н. и соавт. Предварительные результаты апробации иммуносеерментной тест-системы для определения трепонемоспецифических IgM. VIII Всероссийский съезд дерматовенерологов. М., 2001; II: 113-114.]

46. Freguency of identification of treponemspecific antibodies of class lgM at patients with various forms of a syphilis. II ST Congress of dermatology and venereology of Russia. Abstracts. St.Petersburg 2007: 159-160. [Китаева Н.В., Ротанов С.В., Фриго Н.В. и соавт. Частота выявления трепонемоспецифических антител класса IgM у больных различными формами сифилиса. II Всероссийский конгресс дерматовенерологов. Тезисы научных работ. С-Пб., 2007: 159-160.]

47. Kisileva G.A., Tkachev V.K., Bednova V.N. at al.Comparative studying of sensitivity and specificity of three immunoenzymatic test systems intended for identification of immunoglobulins of a class $M$ to the activator of a syphilis. Vestnik Dermatologii i Venerologii 200; (4): 6-10. [Киселева Г.А., Ткачев В.К. Беднова В.Н. и соавт. Сравнительное изучение чувствительности и специсиичности трех иммуноферментных тест-систем, предназначенных для выявления иммуноглобулинов класса М к возбудителю сифилиса. Вестник дерматологии и венерологии 2000; 4: 6-10.]

48. Kulyash G.Yu. About a role of negative results of ELISA-enzymlinked immunosorbent assy on IgM to Treponema pallidum in mistakes at diagnostics and assessment of efficiency of treatment of syphilis.STD. 2002. [Куляш Г.Ю. 0 роли отрицательных результатов ИФА на IgM к Treponema pallidum в ошибках при диагностике и оценке эффективности лечения сифилиса. ИППП 2002; 2: 25—29.]

49. Goh B.T. Syphilis in adults. 2005. URL: http://www. stijournal.com.

50. Seña A.C., White B.L., Sparling P.F. Novel Treponema pallidum Serologic Tests: A Paradigm Shift in Syphilis Screening for the 21st Century. Clin Infect Dis 2010; 51(15): 700—708.
51. Young H., Moyes A., de Ste Croix I., McMillan A. A new recombinant latex agglutination test (Syphilis Fast) for the rapid serological diagnosis of syphilis. Int J STD AIDS 1998; 9: 196-200.

52. Muller F., Moskophidis M. Evaluation of an enzyme immunoassay for IgM antibodies to Treponema pallidum in syphilis in man. Brit J vener Dis 1984; 60: 288-292.

53. Castro R., Prieto E.S., Santo I. et al. Evaluation of enzyme immunoassay technique for detection antibodies against Treponema pallidum. J Clin Microbiol 2003; 41: 250-253

54. McMillan A., Young H. Qualitative and quantitative aspects of serologic diagnosis of syphilis. Int J STD AIDS 2008; 19: 620-624.

55. Loseva 0.K. Syphilis and pregnancy. Basel 2000: 13-18. [Лосева 0.К. Сифилис и беременность. В кн.: Современные методы диагностики, терапии и профиллактики ИППП и других урогенитальных инфекций. Сб. материалов рабочих совещаний дерматовенерологов и акушеров-гинекологов 1999-2000 гг. Базель: Хофффман ля Рош Лтд., 2000: 13-18.]

56. Chebotarev V.V., Zemtsov M.A.. Chebotareva N.V. Serological reactions in syphilis diagnostics: reality and prospects. Russian Journal of Skin and Sexually Transmitted Diseases 2005; (4): 7-10. [Чеботарев В.В. Земцов М.А. Чеботарева Н.B. Серологические реакции в диагностике сифилиса: реальность и перспективы. Российский журнал кожных и венерических болезней 2005; 4: 7-10.]

57. Chebotarev V.V., Zemtsov M.A., Pavlik L.V., Chebotareva N.V. Serorezistentnost problem at the patients with syphilis treated by modern technigues.Clinical dermatology and venereology. 2006; (2): 101-106. [Чеботарев В.В., Земцов М.А., Павлик Л.В., Чеботарева Н.В. Проблема серорезистентности у больных сифилисом, леченных по современным методикам. Клиническая дерматология и венерология 2006; 2: 101-106.]

58. Guseva S.N., Danilov S.I. IgM-FTA-ABS test use in inspection of pregnant women on activity of a syphilitic infection. Russian Journal of Skin and Sexually Transmitted Diseases. 2004; (6): 60—63. [Гусева С.Н., Данилов С.И. Использование теста IgM-РИФабс в обследовании беременных на активность сифилитической инфекции. Рос. журнал кожных и венерических болезней 2004: 6: 60—63.]
59. Lefevre J.-C., Bertrand M.-A., Bauriaud R. Evaluation of Capture Enzyme Immunoassays for Detection Immunoglobulins $\mathrm{G}$ and $\mathrm{M}$ to Treponema pallidum in Syphilis. J Clin Microbiol 1990; 28(8): 1704-1707.

60. Starchenko M.E., Granovich R.I., Danilov S.I. Value of definition of IgM fraction in syphilis diagnostics. Vestnik Dermatologii i Venerologii. 1994; (1): 9—11. [Старченко М.Е., Гранович Р.И., Данилов С. И. Значение определения фракции $\operatorname{lgM}$ в диагностике сифилиса. Вестник дерматологии и венерологии 1994; 1: 9-11.]

61. Mardanly S.G., Shersheva N.N. Development immunofluorescent diag-nostics for identification of antibodies of classes $\lg G$ and $\lg M$ to Treponema pallidum. XII ST Congress of dermatology and venereology of Russia. Abstracts. Moscow 2012. [Марданлы С.Г., Шершнева Н.Н. Разработка иммунофлюоресцентных диагностикумов для выявления антител классов G и M к Treponema pallidum. Тезисы научных работ: XII Всероссийский съезд дерматовенерологов и косметологов. М.: РОДВК, 2012: 36.]

62. Lewis L.L., Taber L.H., Baughn R.E. Evaluation of immunoglobulin $\mathrm{M}$ Western blot analysis in diagnosis of congenital syphilis. J Clin Microbiol 1990; 28: 296-302.

63. Mayer M.P., Eddy T., Baughn R.E. Analysis of Western Blotting (Immunoblotting) Technique in Diagnosis of Congenital Syphilis. J Clin Microbiol 1994; 32(3): 629-633.

64. Ly T.D., Marcenaro C., Dautigny M. Evaluation of four fulliautomated immunoassays for diagnosis of syphilis. 20th Eur Congress of Clin Microbiol and Infect Dis 2010. URL: http://registration.akm. ch/2010eccsmit einsicht.php? XNABSTRACT ID=99115\&XNSPRACHE_ID2.

65. Kubanova A.A., Kubanov A.A., Frigo N.B. et al. XII ST Congress of dermatology and venereology of Russia. Abstracts. 2012. Moscow. Useful model of the biochip for simultaneous definition of antibodies to kcardiolipin and to specific antigens of T. pallidum. [Кубанова А.А., Кубанов А.А., Фриго Н.В. и соавт. Полезная модель биочипа для одновременного определения антител к кардиолипину и специфическим антигенам T. pallidum. Тезисы научных работ: XII Всероссийский съезд дерматовенерологов и косметологов. М.: РОДВК, 2012: 28.]

66. Gomes E., Jespersen D.J., Harring J.A., Binniker M.J. Evaluation of the Bio-Rad BioPlex 2200 Syphilis Multiplex Flow Immunoassay for the Detection of lgG- and IgM-Class Antitreponemal Antibodies. Clin and Vaccin Immunol 2010; 17(6): 966—968.

об авторах:

С.В. Ротанов - д.м.Н., доцент, профессор кафедры дерматовенерологии лечебного факультета ГБоУ ВПО РНИМУ

им. Н.И. Пирогова Минздрава России, главный научный сотрудник отдела лабораторной диагностики инсрекций, передаваемых

половым путем, и болезней кожи ФГБУ «ГНЦДК» Минздрава России, Москва

Р.Н. Чупров-Неточин - научный сотрудник отдела лабораторной диагностики ИППП и болезней кожи ФГБУ «ГНЦДК»

Минздрава России, Москва

Ф.А. Эрматова - аспирант кафедры дерматовенерологии лечебного факультета ГБОУ ВПо РНИМУ им. Н.И. Пирогова

Минздрава России, Москва 